Creation 



\title{
Creation \\ Biblical Theologies in the Context of \\ the Ancient Near East
}

Othmar Keel \& Silvia Schroer

\author{
Translated by \\ Peter T. Daniels
}

Winona Lake, Indiana

Eisenbrauns

2015 
Translation (C) Copyright 2015 by Eisenbrauns. All rights reserved.

Printed in the United States of America.

Translated by Peter T. Daniels from

Schöpfung: Biblische Theologien im Kontext

altorientalischer Religionen,

(C) Copyright 2002, 2nd edition, 2008

Vandenhoeck \& Ruprecht.

www.eisenbrauns.com

\section{Library of Congress Cataloging-in-Publication Data}

Keel, Othmar, author.

[Schöpfung. English]

Creation : biblical theologies in the context of the ancient Near East /

Othmar Keel \& Silvia Schroer ; translated by Peter T. Daniels.

pages $\mathrm{cm}$

Includes bibliographical references and index.

ISBN 978-1-57506-093-4 (hardback : alk. paper)

1. Creation-Biblical teaching. 2. Egyptian literature-Relation to the Old Testament. 3. Assyro-Babylonian literature-Relation to the Old Testament. I. Schroer, Silvia, 1958- author. II. Daniels, Peter T., translator. III. Title. IV. Title: Biblical theologies in the context of the ancient Near East.

BS651.K3913 2015

$231.7^{\prime} 65-\mathrm{dc} 23$

2015009119

The paper used in this publication meets the minimum requirements of the American National Standard for Information Sciences-Permanence of Paper for Printed Library Materials, ANSI Z39.48-1984. @ тм 